\title{
Biodiversity of shipworms (Mollusca: Bivalvia: Teredinidae) in the vicinity of a tropical mangrove ecosystem along Bay of Bengal, Andhra Pradesh, India
}

\begin{abstract}
In efforts to generate information on the occurrence and distribution of marine wood borers from unexplored areas of the east coast, Bhavanapadu $\left(18^{\circ} 32^{\prime} 11^{\prime \prime} \mathrm{N}, 84^{\circ} 18^{\prime}\right.$ 21 "E) back water system, adjoining Bay of Bengal; in Srikakulam District of Andhra Pradesh was surveyed. Infested samples of unprotected stake net poles of Casuarina timber, obtained from the water body, revealed the occurrence of several teredinid borers. Regarding various community characteristics of these wood boring organisms, species richness was found to be 16, density 2036 individuals.m-2, diversity 1.835 and evenness 0.950 . Of these forms, the genus Bankia represented by 7 taxa, followed by Teredo with 4 taxa, were found to be dominant. A few rare teredinids such as Teredo bartschi Clapp, Spathoteredo obtusa (Sivickis), Bankia martensi (Stempell), B. gracilis Moll, B. rochi Moll, B. philippinensis Bartsch and B. destructa Clench and Turner were present in the collections. The occurrence and distribution of all these borers was discussed in the light of available literature from other coastal localities in the country and elsewhere.
\end{abstract}

Keywords: Shipworm, teredinidae, mangrove ecosystem, bay of bengal, bhavanapadu, marine wood borers
Volume I Issue 4 - 2017

\author{
Swain D,' Pachu AV, ${ }^{2}$ Rao MV ${ }^{3}$ \\ 'Ministry of Agriculture, Dairying and Farmers Welfare, India \\ ${ }^{2}$ Institute of Forest Genetics and Tree Breeding, India \\ ${ }^{3}$ Institute of Forest Biodiversity, India
}

Correspondence: Rao MV, Institute of Forest Biodiversity, Plot No 46FF, Sector-7, MVP Colony,Visakhapatnam-530017, India, Tel 9|-89|-94925356|3, Email oarvm1957@gmail.com

Received: August 28, 2017| Published: November 20, 2017

\section{Introduction}

As agents of biodeterioration, the economic significance of marine wood borers is well known because they interfere with the structural and functional integrity of timber installations and craft in marine milieu. ${ }^{1,2}$ In order to reduce the material and monetary losses, various aspects of marine wood biodeterioration have been pursued worldwide for long and among them, the recent works of SanchezAlferz \& Alferz-Leon, ${ }^{3}$ Leonel et al. ${ }^{4}$ Brearley et al., ${ }^{5}$ Santos et al., ${ }^{6}$ Brooks, ${ }^{7}$ Borges et al., ${ }^{8}$ Cragg, ${ }^{9}$ Filho et al. ${ }^{10}$ Borges et al. ${ }^{11}$ deal with the occurrence, diversity or distribution of marine wood borers at various geographical localities. Similar efforts have also been put in India for quite some time. ${ }^{12} \mathrm{~A}$ vast array of structures are used all along the $8129 \mathrm{~km}$ long stretch of the Indian coast and their prolonged use demands sustained inputs to understand all facets of the wood deterioration problem. However, many a gap remains in information on the very occurrence and distribution of the organisms responsible for timber deterioration along the vast sea board of India. ${ }^{13}$ While around 40 localities along the west coast of peninsular India have so far been surveyed for wood borers, only half that number along the east coast was covered. Therefore, in recent years, efforts to generate data from unexplored coastal localities ${ }^{14-16}$ and mangrove wetlands ${ }^{17,18}$ were renewed. In continuation of this endeavour, we surveyed Bhavanapadu back water mangrove ecosystem in Srikakulam District of Andhra Pradesh.

Bhavanapadu, lying between latitudes $18^{\circ} 32^{\prime} 11^{\prime}$ - $18^{\circ} 34^{\prime} 18^{\prime \prime} \mathrm{N}$ and longitudes $84^{\circ} 18^{\prime} 21^{\prime \prime}-84^{\circ} 20^{\prime} 51^{\prime \prime} \mathrm{E}$ is situated $20 \mathrm{~km}$ to the north east of Tekkali town, and constitutes one of the most important fishing harbours of Andhra Pradesh (Figure 1). The back-water system in this region, running more or less parallel to the Bay of Bengal coast, receives fresh water input from a couple of ephemeral streams (Garibulagedda and Desigedda) around, and consists of mangrove wetlands spread over an area of 593 ha. However, most of the wetlands, having been converted into salt pans and brackish water culture ponds, chiefly remain now as a degraded ecosystem, yet inviting lot of migratory birds from places far and wide. Shell collection and stake net fishing are extensively carried out in the locality. A proposal mooted to the establishment of a $2640 \mathrm{MW}$ coal based thermal power project in this wetland ecosystem, became a burning issue during recent years, due to strong opposition from environmentalists and local populace; and therefore, was finally dropped. The latest proposal, however, is to expand the fishing harbor and contiguous wetlands for developing a sea port.

\section{Material and methods}

During the present work, mangrove vegetation in the entire wetland area was surveyed for the incidence of marine wood borers, but as almost all plants were under-shrubs, no incidence was observed. However, Casuarina timber poles (5 to $6 \mathrm{~m}$ height and 28 to $34 \mathrm{~cm}$ girth) without any protective measure, erected in the water body for stake net fishing, were found to be severely attacked by the wood borers and broken off around the intertidal level. Timber samples $(\mathrm{n}=12)$, approximating to $0.05 \mathrm{~m}^{3}$ in volume, were collected from the remains of these poles during the ebb phase of low tide; and pallets of teredinid wood borers retrieved as animals had already perished due to near exhaustion of the timber. A similar technique was followed earlier by Cragg et al. ${ }^{19}$ and Borges et al., ${ }^{11}$ to decipher important scientific facts about teredinids from elsewhere. The species, after identification following Turner ${ }^{20}$ were enumerated and expressed as individuals per unit area. Species diversity and evenness of the borer community were estimated following Magurran ${ }^{21}$ employing the Brillouin index (HB), as the kind of sampling performed in this study falls under non-random method, according to this author. 


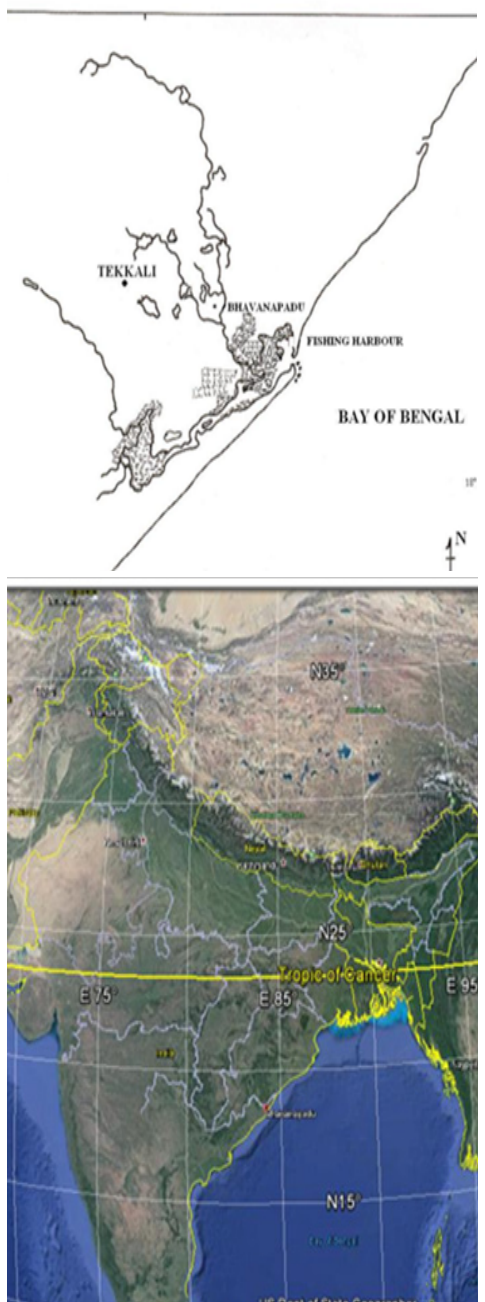

Figure I Bhavanapadu, a tropical mangrove ecosystem along Bay of Bengal, India.

\section{Results}

A total of 5 genera of wood borers belonging to the family Teredinidae (Mollusca: Bivalvia: Myoida) were found to have infested the Casuarina poles erected in the Bhavanapadu back water body (Table 1). Of these, the genus Bankia was represented by the highest number (7) of species; viz., carinata Gray, campanellata Moll and Roch, martensi (Stempell), gracilis Moll, rochi Moll, philippinensis Bartsch and destructa Clench and Turner. This was followed by Teredo with 4 species, namely, parksi Bartsch, furcifera von Martens, bartschi Clapp and clapi Bartsch and Lyrodus with 3 species, viz., takanoshimensis (Roch), pedicellatus (Quatrefages) and bipartitus (Jeffreys). The genera Spathoteredo and Nausitora were represented each by a lone taxon, namely, obtusa (Sivickis) and dunlopei Wright, respectively. Among these species, L. pedicellatus was noticed to be most abundant with 433 individuals $/ \mathrm{m}^{2}$ followed by $T$. bartschi with 368 animals $/ \mathrm{m}^{2}$ and $T$. parksi $/ S$. obtusa to be least abundant with 22 numbers $/ \mathrm{m}^{2}$ each, while all others fell into the intermediate range. Together, these borers were responsible for an average destruction of $90 \%$ to the stake net pole samples.

\section{Discussion}

With regard to various community characteristics of the wood boring organisms that infested unprotected timber in Bhavanapadu back water system, species richness was 16, density was 2036 individuals. $\mathrm{m}^{-2}$, diversity was 1.835 and evenness 0.950 . Besides this species richness, it is quite surprising to note the complete absence of borers belonging to the families Sphaeromatidae (Arthropoda: Crustacea: Isopoda) and Pholadidae (Mollusca: Bivalvia: Myoida) that are usually encountered almost throughout the Indian coastal waters, especially in back waters, brackish waters and estuaries. ${ }^{22}$ Eaton, ${ }^{23}$ however, observed that the rate and type of wood biodeterioration in marine environment is influenced by geographical location, nature of the substrate and position of timber in relation to the mean sea level. The reasons for the absence of Sphaeromatids and Pholadids during the present instance might be due to collection of samples from sub-tidal region and also to the possibility that the poles did not stand through the breeding periods of the two categories of borers, as unprotected casuarina poles last for 3-12 months under marine conditions depending on the vagaries at a given place. ${ }^{24}$ Earlier, Natarajan et al. ${ }^{25}$ also noticed that casuarina poles used in pen-culture at Killai near Chidambaram in Tamilnadu were heavily damaged by marine borers in 6 months. In a recent study on the seasonal abundance of shipworms in mangrove driftwood from a northern Brazilian beach, Filho et al. ${ }^{10}$ could recover only a single species of teredinid, Neoteredo reynei (Bartsch) from as low as 87 logs out of as many as $720 \operatorname{logs}$ collected. Therefore, absence of other groups of borers as in the present instance, or even other genera/species within a group in the collections, may not be surprising.

Table I Teredinids recorded near the tropical mangrove ecosystem of Bhavanapadu

\begin{tabular}{|c|c|c|}
\hline SI. No. & Species & Abundance $\left(\mathrm{no} . / \mathrm{m}^{2}\right)$ \\
\hline I & Lyrodus takanoshimensis (Roch) & 152 \\
\hline 2 & L. pedicellatus (Quatrefages) & 433 \\
\hline 3 & L. bipartitus (Jeffreys) & 152 \\
\hline 4 & Teredo parksi Bartsch & 22 \\
\hline 5 & T. furcifera von Martens & 43 \\
\hline 6 & T. bartschi Clapp & 368 \\
\hline 7 & T. clappi Bartsch & 43 \\
\hline 8 & Spathoteredo obtusa (Sivickis)• & 22 \\
\hline 9 & Nausitora dunlopei Wright & 43 \\
\hline 10 & Bankia carinata Gray & 195 \\
\hline II & B. campanellata Moll and Roch & 195 \\
\hline 12 & B. martensi (Stempell) & 43 \\
\hline 13 & B. gracilis Moll• & 65 \\
\hline 14 & B. rochi Moll & 130 \\
\hline 15 & B. philippinensis Bartsch• & 43 \\
\hline 16 & B. destructa Clench and Turner• & 87 \\
\hline \multicolumn{2}{|c|}{ Species richness: } & 16 \\
\hline \multicolumn{2}{|l|}{ Density: } & $2036 \mathrm{no} . / \mathrm{m}^{2}$ \\
\hline \multicolumn{2}{|c|}{ Brillouin diversity index $(\mathrm{HB})$ : } & 1.835 \\
\hline \multicolumn{2}{|c|}{ Brillouin evenness index $(E)$ : } & 0.95 \\
\hline
\end{tabular}

-First record to peninsular Indian east coast

- Second report from India

- Second report to peninsular Indian east coast 
The occurrence of B. destructa and B. philippinensis in Indian waters was reported for the first time for the Krishna estuarine mangroves $;{ }^{17}$ and that of $B$. martensi for the Sarada-Varaha estuarine mangroves; ${ }^{18}$ therefore, our present records become the second for India. The latter authors also found B. gracilis to be a new record for the Indian mainland, and therefore its report now becomes second to the mainland. Incidentally, the present record of the above four taxa is also from mangrove wetlands, though not from mangrove timber itself.

So far, L. takanoshimensis, L. bipartitus and T. bartschi are known to be occurring exclusively along the mainland east coast ${ }^{13,17}$ either in mangrove or coastal habitats. Spathoteredo obtusa was recorded for the first time for the mainland east coast, although recorded earlier for the sub-oceanic Andaman-Nicobar Islands, ${ }^{26,27}$ West coast ${ }^{28}$ and Lakshadweep Archipelago. ${ }^{29}$ The remaining species, namely, $L$. pedicellatus, T parksi, T furcifera, T clappi, N. dunlopei, B. carinata and $B$. campanellata, within the limits of their temperature and salinity tolerance; are more or less cosmopolitan in their occurrence along the Indian coasts. ${ }^{22}$

In recent years, a number of wood borer species encountered during the present work was also recorded for various other mangrove environs of the world. Among others, the occurrence of T. bartschi was reported from the mangroves in Mamanguape estuarine region of the north-eastern Brazil by Leonel et al. ${ }^{4}$ and the presence of $B$. rochi and L. pedicellatus in the mangrove habitats of the Burrup peninsula in Western Australia by Brearley et al. ${ }^{5}$ Like-wise, Beasley et al. ${ }^{30}$ identified the presence of L. pedicellatus and Teredo spp. from Ajuruteua Peninsula of northern Brazil while Borges et al. ${ }^{11}$ recognized the incidence of $L$. pedicellatus in the Tagus Estuary, Borges et al. ${ }^{31}$ found the occurrence of B. carinata, L. pedicellatus and T. bartschi in European coastal waters.

\section{Conclusion}

The current work, though limited in nature with several other limitations, definitely indicates, the presence of a good number of rare marine wood boring teredinid species in Indian waters. This underlines the need for intensive collections along the vast coastal stretches of the country, particularly from mangrove habitats, to generate sufficient information on this economically important group. A baseline data on marine timber dwellers thus established is essential for developing suitable wood deterioration control measures that prolong the service life of timber used under marine conditions. ${ }^{32,33}$

\section{Acknowledgements}

The authors are highly thankful to the Director General, Indian Council of Forestry Research and Education, Dehra Dun for encouragement. Thanks are also due to the Director and Group Coordinator (Research), Institute of Wood Science and Technology, Bangalore for their keen interest in the work.

\section{Conflict of interest}

Author declares that there is no conflict of interest.

\section{References}

1. Tanal V, Matlin A. Marine borer attack on submerged timber structures: Investigation, protection and control. Port Technology International. 1997;5:185-191.
2. Cragg SM, Pitman AJ, Henderson SM. Developments in the understanding of the biology of marine wood boring crustaceans and the methods of controlling them. Intnl Biod \& Biodeg. 1999;43(4):197-205.

3. Sanchez-Alferez AS, Alvarez-Leon R. Neoteredo reynei (Bivalvia: Teredinidae) in mangrove swamps of the Colombian Caribbean. Revista de Biologia Tropical. 2000;48(2-3):720.

4. Leonel RMV, Lopes SCBC, Aversari M. Distributation of wood boring bivalves in the Mamanguape River estuary, Paraiba, Brazil. J Mar Biol Assoc UK. 2002;82(6):1039-1040.

5. Brearley A, Chalermwat K, Kakhai N. Pholadidae and Teredinidae (Mollusca: Bivalvia) collected from mangrove habitats on the Burrup Peninsula, Western Australia. In: Wells FE, Walker DI, editors. The marine flora and fauna of Dampier. Perth, Western Australia, Australia; 2003. p. $345-361$.

6. Santos SML, Gloria DA, Gomes DJ, et al. Coletors artificians para obtencao de turus (Bivalvia: Teredinidea). In: Anais F, editors. Congtesso fde Ecologia do Brasil-6. Fortaleza Universidale Fedoral do Ceara cap, Brazil; 2003. p. 457-458.

7. Brooks RA. Discovery of Sphaeroma terebrans, a wood boring Isopod, in the Red mangrove, Rhizophora mangle, Habitat of Northern Florida Bay. Ambio A Journal of the Human Environment. 2004;33(3):171-173.

8. Borges LMS. Biogeography of wood boring organisms in European coastal waters and new approach to controlling their attack. $\mathrm{PhD}$ thesis, Portsmouth University, UK; 2007.

9. Cragg SM. Marine wood boring invertebrates of New Guinea and its surrounding waters. In: Beehler B, Marshall A, editors. The ecology of Papua. Periplus, Singapore; 2007. p. 539-563.

10. Filho CS, Tagliaro CH, Beasley CR. Seasonal abundance of shipworm Neoteredo reynei (Bivalivia: Teridinidae) in mangrove drift wood from a northern Brazilian beach. Iheringia Ser Zool Porto Alegre. 2008;98(1):17-23.

11. Borges LMS, Valente AA, Palma P, et al. Changes in the wood boring community in the Tagus Estuary, a case study. Mar Biod Rec. 2010;3(841):1-7.

12. Wagh AB. Wood boring organisms. In: A list of selected references on biodeterioration in Indian waters. National Institute of Oceanography, Goa, India; 1985.

13. Rao MV, Ba1aji M, Pachu AV. Marine wood borers of BhimunipatnamVisakhapatnam coast, Bay of Bengal, India. J Timb Dev Assoc India. 2008;54:59-77.

14. Vishwakiran D, Thakur NL, Ragukumar S, et al. Spatial and temporal distribution of fungi and wood borers in the coastal tropical waters of Goa, India. Botanica Marina. 2001;44(1):47-56.

15. Tarakanadha B, Rao KS. Seasonal settlement of wood borers in Krishnapatnam harbour, Andhra Pradesh, East coast of India. J Inst Wood Sci. 2007;17(5):277-285.

16. Rao MV, Balaji M, Pachu AV. Occurrence and species diversity of marine wood borers from Chippada to Rambilli in Visakhapatnam District on the east coast. VSR \& NVR College, Tenali, India; 2008. p. 23-24.

17. Pachu AV, Rao MV, Balaji M. Marine wood borer fauna in mangroves of the Krishna estuary, East Coast, India. In: Solomon Raju AJ, editor. Bioresources conservation and management. Today and Tommorrow's Printers and Publishers, New Delhi, India; 2008. p. 41-51.

18. Rao MV, Balaji M, Pachu AV. Occurrence and species diversity of marine wood borers at Kothakoduru and Bangarammapalem mangroves. Poster presented at the National Workshop on Mangroves of India: Biodiversity, protection and environmental services. Institute of Wood Science and Technology, Bangalore, India; 2008. p. 7-8. 
19. Cragg SM, Jumel MC, Al-Horani FA, et al. The life history characteristics of the wood boring bivalve Teredobartschi are suited to the elevated salinity, oligotrophic circulation in the Gulf of Aquaba, Red Sea. J Exp Mar Biol Ecol. 2009;375(1-2):99-105.

20. Turner RD. Identification of marine wood-boring molluscs. In: Jones EBG, Eltringham SK, editors. Marine borers, fungi and fouling organisms of wood. Organization of Economic Cooperation and Development, Paris, France; 1921. p. 18-64.

21. Magurran AE. Ecological diversity and its measurement. Croom Helm Limited, London, UK; 1988. p. 179.

22. Santhakumaran LN. Marine wood-borers of India-An annotated bibliography. Institute of Wood Science and Technology. Bangalore, India; 1994. p. 262.

23. Eaton RA. Preservation of marine timbers. In: Findley WPK, editors. Preservation of timber in the Tropics. Adam and Charles Black, London, UK; 1985. p. 157-191.

24. Rao MV, Balaji M, Kuppusamy V, et al. Biodeterioration of timber in Indian coastal waters. Third progress report: 1982-2005. Institute of Wood Science and Technology, Bangalore, India; 2007. p. 198.

25. Natarajan MV, Nalluchinnappan I, Mohammed Ali SM. Problems in penculture experienced at Killai during 1982-1986. In: Abstracts of the all India symposium on aquatic organisms, Poondi, India; 1987. p. 9-11.
26. Taki I, Habe T. On the teredinid species of Ambon and Nicobar. Kairuigaku Zasshi Oshima. 1945;14(1-4):108-123.

27. Santhakumaran LN, Srinivasan VV. Marine wood borers of AndamanNicobar Islands with notes on control measures and their distribution along the east coast of India. Mahasagar Bull Nat Inst Oceanogr. 1988;21:13-21.

28. Dharmaraj K, Balakrishnan Nair N. Occurrence of Spathoteredo Moll (Bivalvia: Teredinidae) in India. Curr Sci Bangalore. 1981;50:1084-1085.

29. Balakrishnan Nair N, Salim M. Marine timber destroying organisms of the Andaman-Nicobar Islands and the Lakshadweep Archipelago. Rec Zool Sur, Calcatta, India; 1994;159:1-87.

30. Beasley CR, Fernandes CM, Gomes CP, et al. Molluscan diversity and abundance among coastal habitats of northern Brazil. Ecotropica. 2005;11:9-20.

31. Borges LMS, Merckelbach LM, Sampaio I, et al. Diversity, environmental requirements, and biogeography of bivalve wood-borers (Teredinidae) in European coastal waters. Frontiers in Zoology. 2014;11:1-13.

32. Dev Roy MK. Marine wood-borers of Andaman and Nicobar Islands with key to species. J Environ Sociobiol. 2006;3(2).

33. Sivrikaya H. Basilica of the sea destroying wood. ZKÜ. Bartin Faculty of Forestry. 2004;1(1):136-141. 